\title{
Participation On Women's Non-Governmental Organizations: A Conceptual Framework
}

\author{
Noorfadhleen Mahmud, Nadrawina Isnin,Asmahani Mahdi, Angie Edward Daung, Noni \\ Harianti Junaidi
}

\begin{abstract}
Women in Non-governmental Organizations (WNGOs) can be define as women's movement, women's pressure group or interest group, women's association and women's in civil society. It is a non-profit institution that empowered to address women's issues which the government has not been able to manage. It is a mediator whereby women issues can be brought to the attention of government. Since independence, more than 50 WNGOs have been established in Sarawak and this is an important indication that Sarawak women have realized their important roles and contribution to the society. Through WNGOs, Sarawak women have played an important part in promoting the development of society. Their roles and contribution through civil society have made society realized of the importance of their role in highlighting issues that need to be addressed. Even though the increasing number of WNGOs establishment has proven that they are needed in the development process but the issues of participation still arise. This paper makes an attempted to throw light on the various factors on women motivation and challenges that inhibit Sarawak women to participate in WNGOs in Sarawak.
\end{abstract}

Key words: Non-Governmental Organization, Participation, Motivation, Challenges

\section{INTRODUCTION}

Non-governmental organizations (NGOs) play significant roles, to encompassing and empowering communities to develop and use their own inventiveness to develop themselves (Nikkhah et. al, 2010). Meanwhile Alatas (2003) claimed that, NGOS and non-state actors are the components of civil society which do not make up the state machinery or government, although they may work closely with and contribute to the state decision-making apparatus. This shows that their roles and contributions are indeed significant to fill the gap that government could not cater for.

Apparently, Kartina A.T (2010) defined interest group (IGs), NGOs, social organizations, social movements, religious groups or nationalists are non-governmental organizations with their own motives, activities and

strategies to ensure that the organization achieves the objectives that have been channeled for the benefit of

Revised Manuscript Received on April 19, 2019.

Noorfadhleen Mahmud, Faculty of Administrative Science \& Policy Study,Universiti Teknologi MARA, Sarawak, Malaysia.

Dr. Nadrawina Isnin., Faculty of Administrative Science \& Policy Study,Universiti Teknologi MARA, Sarawak, Malaysia

Asmahani Mahdi, Faculty of Business Management ,Universiti Teknologi MARA, Sarawak, Malaysia

Angie Edward Daung, Faculty of Business Management ,Universiti Teknologi MARA, Sarawak, Malaysia

Dr. Noni Harianti Junaidi., Faculty of Administrative Science \& Policy Study,Universiti Teknologi MARA, Sarawak, Malaysia members, target groups, or communities. The democratic state of life helps NGOs to mobilize human resources, funds, and skills freely in the constitutional guarantees supported by the constitution (Kartina A.T 2010).

There are various natures of NGOs established and their roles are to empower the community. In relation to this, Nikkah et. al., (2010) has mentioned that NGOs at community level can play an imperative role in associate women to challenge customs, ideas and belief which propagate imbalanced gender relations.

On a similar vein, Nadrawina I., Aishah I. and Noorfadhleen M. (2010), commented that most of the NGOs especially women associations are involved in the programs such as training women to participate in community development and it is aims to increase the spirit of volunteerism. Thus involvement in such activities could unearth the talent and leadership capability among women to play an effective role at home or society. It is also hoped that women can equipped them with relevant knowledge and smart women did not only have university degree but also being aware of the welfare and their privilege. Furthermore according to Weiss, M. L., (2003), Malaysian NGOs have made imperative contributions to raise a legitimately prone and socially aware community, carrying key issues to public reputation and fostering a significant core group within civil society that able to rally mass opinion at crucial occasions in support of social, political and economic reforms.

Shvedova, (2005) pointed out that the central charge of the women's movement is to instill the right type of selfreliance and decisiveness among them. It needs frontrunners who can express right socio-political messages and motivate confidence. It is also crucial to have novel ways of thinking and acting, educational activities, research about women's status, and means of communication among women's organizations. The challenge for women is to construct a society according to a model that reflects their values, strengths and aspirations and thereby emphasize their interest and participation in political processes. (Shvedova, N. 2005).

As Nadrawina I., Aishah I. and Noorfadhleen M. (2010) explained based on activities and increasing numbers of women NGOs groups shows that Sarawak civil based 
society has played a part as strategic partner in country development and these will lead them to participate in decision making power and power sharing position in various sectors.

\section{WOMEN'S PARTICIPATION ISSUES IN WNGOS}

There are two issues that we acknowledged in conducting this study. First, is from Mediterranean Institute of Gender Studies (2006). The findings from this report stated that, the involvement of women and men are equivalent statistically but, generally in term of extent of involvement or participation are greatly lopsided towards men. This study proposed, it is needed to strengthen and find out the obstacle factors due to the participation of WNGOs and the hurdles to a better involvement need to be lightened. By empowering WNGOs will construct a critical mass and this is important in promoting and addressing issues that are importance to women at large. Apart from that, this scenario is significant with the Malaysia's National Policy on Women objectives which is to ensure justifiable distribution of resources and development opportunities between men and women and to incorporate women into all sectors of development in accordance with their capabilities and needs (Aminah Ahmad 1998). Thus, from the development point of view, participation among women is crucial and all development programs must not marginalize them. To that we need to analyze the reason factors that motivate women to participate in WNGOs especially, so that their contribution can be highlights.

However the participation among young women seems to be not encouraging. Noorfadhleen M., Nadrawina I. and Azlina B. (2012) revealed that participation among young women in activities conducted by PPWS (Persekutuan Perkumpulan Wanita Sarawak) is very low. The young women perceived that the activities conducted are unsuitable for their age. Moreover, women refused to participate in NGOs or women's NGOs because of few reasons. The reasons were, nobody encouraged the women to participate in women organization; women assume that the organization did not contribute anything to them; ignorant about the existence of women organization in Sarawak and finally; the respondents' organization prohibited them to get involved actively in the civil based societies (Noorfadhleen $M$. Nadrawina I. and Azlina B. 2012). These findings can be related to the Shahirah Sharifah (2015) study. She asserted that among the factors identified inhibiting the active involvement of women in politics and leadership is the refusal of young women to actively engage in politics, career and family demands, cultural and religious barriers, and lack of support from their own group.

\section{OBJECTIVES OF THE STUDY}

This study attempts to give insight view on the factors that motivates and discover challanges factors that inhibit them to participate in women's NGOs.

\section{LITERATURE REVIEW}

A. Participation and Community Participation Leads to Women empowerment through Participation in WNGOs

According to Asnarulkhadi A.S \& Muhammad N. N., (2012), participation is the mutual efforts by members of an organized group belligerent to achieve a stated objective. It is a practice where associates members able to identify and solve the problems or issues to them, able to decide suitable decisions about the issues which effected their lives in order to achieve and enhanced towards sustainable development. That means participation involves actions and social interactions among every member as well as their involvement toward a preferred result that can bring about their welfare. Thus, there is a need to ensure vigorous support and participation of women involved in the development process.

Taking into consideration the claims by Zahirinia, M., and Nikkhah, H. (2012), participation strengthens the individual capability, generates prospects for a positive explanation of problems, and inspires public commitment. Individual involvement in team and managerial agendas promotes community empowerment and leads to individual empowerment.

Likewise, Hoque, M., \& Itohara, Y. (2009) pointed out the participation in the conception of women's empowerment as where they decide in the same way as men. Mobilization is compulsory in order to grasp this equal. To increase their representation, they are encouraged to organize themselves and work collectively. With these, it will lead to improve their empowerment. Hoque, M., \& Itohara, Y. also stated clearly that through participation in association such as micro-credit NGO, women can participate in the income earning activities which make them resourceful and make them empowered which is really important for defensible rural development and women empowerment.

Participation will also facilitate and enhance development. To achieve those women must play their roles to ensure the development and empowering process achieves the targets. This is very important for women's NGOs to uplift their roles and to assure women empowerment succeed.

Further discussion on participation is by Waweru, (2015). Waweru asserted that when individual participate in community development programs it will motivate them to achieve tangible and non-tangible benefits as well as short and long term gains. The influences of community participation in development are the projects that cater for their needs and give benefits as returns. Furthermore, people participate in development agenda as to change their lives, promote equity, contribute in decision-making processes, influencing beneficiary communities to more democratic development and strengthening selfdetermination. Waweru also has come out with nine dynamics elements which uphold beneficiary community participation in the community driven development. The nine dynamics elements are i) financial benefits, ii) material benefits, iii) development interest, iv) development need, v)pervious development materials vi)wanting to belong, vii) to serve the community, viii)projects meet needs ix) peer pressure (Waweru2015). 
In this study we will relates the women participation and women empowerment with dimension that had been pointed out by Itohara and Hoque, (2009). Itohara and Hoque had come out with five dimensions on women participation and women empowerment. There are, i) Women are merely passive beneficiaries of welfare benefits, ii) Equality of access to resources such as educational opportunities, land and credit, iii) Awareness-raising on gender gaps or gender inequalities, iv)Participation will leads to mobilization as well as increased representation, v) Control over decisions regarding their lives.

Women will be empowered through participation because they will develop their potential and contribute in development process. Not only that, they will also be able to have power, develop their skills, knowledge, aware on capacity building and these will make them participate in decision making process.

B. Factors that Inhibit Women to Participate in WNGOs

Gamisonia Nino, 2017 pointed out few factors that hinder the effective role of women in economic development that we can relates to participation in WNGOs. The seven are; low-level of educational background, shortage of initial capital, lack of business knowledge, deficiency of women's cooperation activities monitoring, the dependence of the family on women's, lack of interest to work in a group and lack of confidence and inferiority. Among these obstacles, the most and the often still unsolved problem is the traditional backward attitudes, beliefs and customs of the society towards women.

Huma Zafar 2016 in her thesis entitles Empowering Women: NGOs Project Impacts in Baluchistan-Pakistan highlighted four factors that affecting empowerment. These factors lead to hindering women to get involved in women's NGOs. The four factors are i) Patriarchy dominance ii) Constraints on women's movement iii) Illiteracy iv) Low female status leads to poverty and lack of access to resources

Those factors that inhibited women from actively involved in WNGOs will surely affect the development process. Women will not be able to contribute in the development program and their skill and expertise in certain field will not be highlighted.

\section{METHODOLOGY/MATERIALS}

This study is prominently based on qualitative method. The data collected through intensive interview with the women who actively involved in WNGOs in Sarawak. The interview sessions covered the aspect of factors that motivates and hinders women to participate in WNGOs. We managed to interview six prominent women from various natures of WNGOs in Sarawak. There are five aspects being asked during the interview: (i) factors that motivate women to participate in WNGOs, (ii) length of participation, (iii) position in WNGOs, (iv) aspirations and hope to the WNGOs, (v) constraint factors of women participation in WNGOs.

\section{RESULTS AND FINDINGS}

\footnotetext{
A. Factors that motivates woman to participate in WNGOs.
}

To shed light on the factors that motivate women participation in WNGOs we asked the informants to describe the reasons behind their involvement in the institutions. Our first informant (Pseudo $1=\mathrm{P} 1$ ) is representing Angkatan Belia Islam Malaysia- Helwa (ABIM). She has been with ABIM since 2014. She holds a position as Education Exco in ABIM. The factor that motivates her to participate in this NGO is because she wants to serve the society from the Islamic perspectives. She also thinks that with her involvement, it gives her reflections to be a good Muslim here after.

To contribute and serve the society is the motivation factor that leads our second informant (P2) to get actively involved in one of the established women's NGO which focus on economic empowerment, known as DEWANITA. She has been with DEWANITA for more than five years. She really hoped that by giving back to the society especially women, women can be empowered and have knowledge to change their life.

The third informant (P3) was from Pertubuhan Permekasaan Wanita dan Keluarga Petra Jaya (PPWKPJ). This lady is very committed to help poor families. What motivates her to get involved in WNGOs is she is very passionate to give ideas on how to strengthen the family institutions.

The fourth informant $(\mathrm{P} 4)$ stated that the reason she was involved in WNGOs is because she think that by helping others, it will change the world. With the involvement she can give information and ideas to facilitate the activities or programs organized by WNGOs.

The fifth informant (P5) stated that the reasons she joined the WNGO which focus on empowering women through business are to develop the networking with fellow women's entrepreneurs, meeting establish women in the same and others field and getting connected with relevant agencies that can foster the business empire. As she has been involved in the NGOs for nine years, she hoped that she can maintain the great effort and support from other stakeholders and hopefully more business women can join the established women's NGO.

Finally the sixth informant (P6) was from one of WNGO which advocate with the subsidiary agency of government. She stated that what made her motivated to contribute in the WNGO is because she wanted to improve and sustain her profile career. A part from that, she is eager to help the local community and as a platform to increase her knowledge and experience. By giving the effort and volunteer in some activities she hope that she could assist the institution in strengthening its financial funds. She also agreed that with her involvement she has gain a lot of information and new knowledge such as advocacy, human rights and employment rights. Therefore, based on the informants responses, it is a clear indication that at these points of view, Nikkah H.'s, (2010) justification seems to fit in the responses we received from the informants. That is, participation 
reinforces sense of personal ability, creates expectations for successful solution of problem, and encourages civic commitment Nikkah H.'s, (2010).

All six responses from the informants are align them with opinions by Waweru R., (2015). Here, Waweru R., agreed that people's participation can be based on the fact that people have the ability to carry out activities suited to their needs by becoming empowered to develop themselves in a collective effort. The involvement of women in WNGOs could also give opportunity to financial, material and nonmaterial benefits. Non-material benefits will give experience to the individual who provides them with insights, confidence and skills to solve existing problems (Waweru R., 2015). Itohara and Hoque, (2009) also support the reason of participation in women's NGOs for welfare service to the society.

\section{B. Factors that inhibit women participation in} women's NGOs

As for factors that hinders women participation in the WNGOs, all six informants agreed that women are not actively involved in women's NGOs due to lack of time. This is because they focus more on family matters. This is exactly of the thoughts of Huma Z. (2016). As Huma Z. (2016) pointed out, women are bound to their home, due to their responsibilities of child care, household chores.

What is more, P1 and P2 also agreed that before marriage, women were actively involved in NGOs, but after marriage, they quit. This is because the spouses refused to understand the reason behind actively involved in NGOs.

The other factor which as an obstacle to the women participation in WNGOs is women have limited knowledge which leads to lack of awareness towards the benefits of joining WNGOs. These factors were seconded by P2, P3 and P6. Similar as noted by Huma Z, (2016), once women lack of access to resources will force them to unaware of knowledge and lack of mobility can create isolation and away from development process.

Furthermore other reason that inhibits women participation in WNGO is low self -esteem. Women feel intimidated yet they feel uncomfortable to meet and socialize with the society. These statements were agreed by $\mathrm{P} 1, \mathrm{P} 2$ and $\mathrm{P} 6$.

P1, P2, P3, P4, and P5 also share similar statement which are, men still think that women are not capable to handle activities. Some men think that women cannot be so loud in order to give opinions. Some men refused to give cooperation to women's group activities. As Huma Z., (2016) justified that Patriarchy or Male Dominance is a normative system that constrains women's empowerment especially in socio-economic. For men, independence is seen as a challenge to male authority perhaps power structure privileges men and men feel insecure if power is extended to women.

\section{CONCLUSION}

This study revealed that the factors that motivate women's participation in WNGOs are to contribute and serve the society, to gain knowledge and skills, to develop networking, to enhance career path and to develop selfesteem. Meanwhile factors that hinders women for being actively involved in WNGOs are lack of time due to their focus on family and house matters, men still think that women can't do what men can do, lack of awareness on benefits in joining the women's NGOs, limited access to knowledge on NGOs and women feel intimidate and not confident to be socialize in NGOs. The findings of this study are also consistent with studies conducted by past researchers such as, Hoque, M. \& Itohara Y. (2009) Waweru R. (2015), Huma Zafar (2016), Asnarulkhadi A.S \& Muhammad N. N., (2012) and Zahirinia M. \& Nikkhah H. (2012).

\section{ACKNOWLEDGEMENT}

We would like to thank our respondents for being cooperative during the interview session.

\section{REFERENCES}

1. Abu Samah, A., \& Ndas Ndaeji, M. Asnarulkhadi Abu Samah and Muhammad Ndas Ndaeji. Women Participation In Self-Help Development Projects As An Instrument For Rural Women Empowerment In Nigeria. (2012). Journal of American Science (Vol. 8). Avaiable: http://www.americanscience.orghttp//www.americanscie nce.org. 101

2. Allah Nikkhah, H., \& Redzuan, rof. The Impact Of NGO' Functions On Women Participation In Capacity Building Programmes In Iran. 2010.

3. Ahmad A, Ahmad A. Women in Malaysia. Asian Development Bank, Programs Department East; 1998 Dec.

4. Aishah I., Nadrawina I. \& Noorfadhleen M. In Sabariah Putit (Ed.), Sarawak Women Treading The Path Of PostIndependence Years-Women In Leadership And Decision Making, , (2010), pp. 25-77 Kuching. Sarawak Women and Famili Council.

5. Alatas SM. The Role of NGOs and Non-State Actors in Malaysia's Foreign Policy Formulation During the Mahathir Era. Akademika. 2003 Jan 2;62(1).

6. Gamisonia Nino. Challenges and opportunities in achieving gender equality and the empowerment of rural women and girls Rome, Italy , 20-22 September

7. Hoque, M., \& Itohara, Y. Women Empowerment through Participation in Micro-Credit Programme: A Case Study from Bangladesh. Journal of Social Sciences. 2010. Available: http://doi.org/10.3844/jssp.2009.244.250

8. Kartina Abu Talib Masyarakat Sivil di Malaysia: Isu dan Strategi.Eubios Jurnal of Asian and International Biotechics Vol (6), November Kartina A. T. (2010)

9. Mediterrenean Institute of Gender Studies, Participation in NGOs: The Gender Gap in Participation 2006

10. Noorfadhleen M., Nadrawina I. \& Azlina B. Women In Civil Based Society: A Case Study Of Persekutuan Perkumpulan Wanita Sarawak (PPWS) 2012.

11. Shvedova N. Obstacles to women's participation in parliament. Women in parliament: Beyond numbers 2005 May 24;33.

12. Syahirah, Sharifah, Regional-Global Governance Network on Women?s Rights:

CEDAW and its implementation in ASEAN countries Procedia - Social and Behavioral Sciences, 2015 , vol. 172 , p. $519-524$ 
13. Waweru, R. (2015). Factors which promote community participation in the community driven development approach. International Journal of Humanities \& Social Science Studies, 6959(13), 2349-6959

14. Weiss ML. Malaysian NGOs: History, legal framework and characteristics. InSocial Movements in Malaysia 2003 Sep 2 (pp. 28-55). Routledge

15. Zafar, H. (2016). Empowering women: NGOs project impacts in baluchistan-pakistan Avaiable: http://search.proquest.com.ezaccess.library.uitm.edu.my/ docview/

16. Zahirinia M, Nikkhah H. A. Women empowerment through participation in NGOs' programmers. Culture and Society in The Middle East. 2012; 1:75-100.

\section{AUTHORS PROFILE}

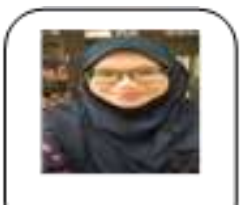

Noorfadhleen Mahmud teaches in Bachelor in Administrative Science \& Policy study at the Faculty of Administrative Science \& Policy Study, Universiti Teknologi MARA (UiTM) since 2005. She received her Bachelor in Administrative Science and Policy Study in UiTM and graduated in Master of Arts (Political Science) at Universiti Kebangsaan Malaysia (UKM) in 2009. Her areas of research interest include project management, gender studies, service management, quality management and public administration. She has published numerous articles in local and international refereed journals. She had received three grants from UiTM to produce research entitled Women In Civil Based Society: A Case Study Of Persekutuan Perkumpulan Wanita Sarawak (PPWS), Political Participation And Voting Preference Of Rural Youths: A Study Of The 2016 Sarawak State Election In Tasik Biru Bau Sarawak and Sarawak State Election 2016: Voting Preference Towards Candidates In N16 Muara Tuang \& N17 Stakan.

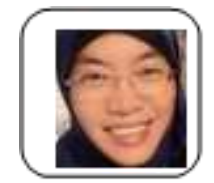

Nadrawina Isnin, PhD teaches students from the Faculty of Administrative Science \& Policy Study, Universiti Teknologi MARA (UiTM) since 1997. She received her Bachelor in Public Administration (honors) from Universiti Utara Malaysia (UUM) in 1992 and graduated in Master of Arts (Political Science) at Universiti Kebangsaan Malaysia (UKM) in 2005. Her areas of research interest include social issues, project management, political science, electoral studies, gender studies and public administration. She has published numerous research articles and proceedings in local and international refereed journals. She had received three grants from UiTM to produce research entitled Women In Civil Based Society: A Case Study Of Persekutuan Perkumpulan Wanita Sarawak (PPWS), Political Participation And Voting Preference Of Rural Youths: A Study Of The 2016 Sarawak State Election In Tasik Biru Bau Sarawak and Sarawak State Election 2016: Voting Preference Towards Candidates In N16 Muara Tuang \& N17 Stakan.

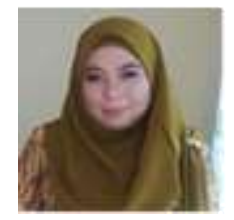

Asmahani Mahdi graduated from Universit Teknologi MARA (UiTM) Shah Alam with a Bachelor of Office System Management (Hons.) in 2006 and holds a Master in Office System Management in 2010. She has produced several proceedings paper focus on organizational commitment, techno-stress, office workers behavior, hygine factor and islamic management. Her broad areas of interest include document processing, office administration, organizational behavior, executive notetaking and records management to students majoring in office management.

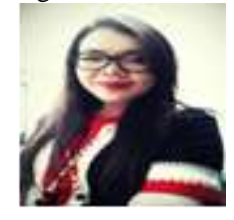

Angie Edward Daung is a lecturer with the Faculty of Business and Management, Universiti Teknologi MARA (UiTM), Sarawak Campus. She holds a Master in Office Systems Management and a Bachelor Degree in Office Systems Management (Hons), both from Universiti Teknologi MARA (UiTM) Malaysia. Her teaching areas include document processing, office administration, communication and corporate compliance. She is interested with in multi-disciplinary research topics such as religious, ethnics and culture, corporate social responsibility, workplace environment, human resource practices and management. She also has produced several proceedings paper on the related topics and participated in several local and international conferences throughout Malaysia and Indonesia.

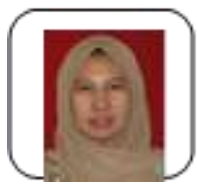

Dr. Noni Harianti Bt Junaidi is currently attached to the Faculty of Administrative Science and Policy Studies, Universiti Teknologi MARA. She did her first degree in Public Management, master's degree in public administration and Philosophy Doctorate in Public Management from Universiti Utara Malaysia (UUM). She has been in the academic field for almost 17 years. To his credit Dr Noni has written more academics articles and paperwork for publication in journals and presented in conference as well. She also has involved in six research projects and consultation. To date she has personally completed four research projects and two are still in progress. Besides, she also involved as reviewer and panel of editor of PROFES Journal and has also supervised research projects at the undergraduate and post-graduate level in the university. She was also involved as a panel of evaluator for Malaysia Qualification Agency (MQA) since 2013-2019. 